\title{
СУИЦИДАЯЬНОЕ ПОВЕДЕНИЕ У ДЕТЕЙ И ПОДРОСТКОВ КОРЕННЫХ НАРОДОВ СИБИРИ: СОЦИААЬНЫЕ ФАКТОРЫ РИСКА
}

\section{Н.Б. Семёнова}

ФГБНУ «Федеральный исследовательский центр «Красноярский научный центр Сибирского отделения Российской академии наук", НИИ медицинских проблем Севера, г. Красноярск, Россия

\section{Контактная информация:}

Семёнова Надежда Борисовна - доктор медицинских наук (SPIN-код: 8340-6208, ORCID iD: 0000-00022790-7740, Researcher ID: U-4748-2017). Место работы и должность: главный научный сотрудник ФГБНУ «Федеральный исследовательский центр «Красноярский научный центр Сибирского отделения Российской академии наук", НИИ медицинских проблем Севера. Адрес: 660036, г. Красноярск, Академгородок, д. 50. Телефон: (913) 539-86-02, эмектронный адрес: snb237@gmail.com

Показатели смертности от самоубийств среди детей и подростков коренных народов Сибири во много раз превышают средние значения по Российской Федерации (РФ). Это требует тщательного анализа данного социального явления и объяснения его причин. Цель исследования: оценить распространённость и выраженность социальных факторов риска, ассоциированных с суицидальным поведением, у подростков коренных популяций Сибири - якутов, эвенов, эвенков, алтайцев, агинских бурят и тувинцев. Объект и методы исследования. Методом анонимного анкетирования обследован 781 подросток разных этнических групп: якуты (181), эвены и эвенки (63), алтайцы (103), буряты (228), тувинцы (206). Якуты, эвены и эвенки проживают в северных районах Сибири, алтайцы, буряты и тувинцы - в южных. Средний возраст составил 16,5 лет. Изучены три группы факторов: І. Семейные факторы риска (материально-бытовые проблемы семьи; проблемы внутрисемейных отношений; наличие конфликтов в семье; алкоголизация родителей). II. Риски, связанные с системой взаимоотношений (проблемы в отношениях с родителями; учителями; со сверстниками; с противоположным полом). III. Риски девиантности (употребление алкоголя и/или психоактивных веществ (ПАВ); наличие друзей, употребляющих алкоголь или ПАВ; наличие друзей с криминальными наклонностями). Статистическая обработка данных проводилась с использованием программы STATISTICA for Window Version Х. Результаты. Семейные риски выявлены у 7,8-29,8\% подростков; риски, связанные с системой взаимоотношений, у 9,6-43,1\%; риски девиантности у 7,8-69,8\%. Сочетание негативного влияния двух или трёх факторов выявлено у 7,0-29,6\% подростков. Распространённость социальных факторов риска чаще встречается у подростков, проживающих в северных районах Сибирского региона - якутов, эвенов, эвенков $(\mathrm{p}<0,01)$. У подростков тувинской национальности материально-бытовые проблемы и алкоголизация родителей встречаются также часто, как и у подростков, проживающих на севере. У тувинцев чаще, чем у других этнических групп, выявляются сочетания двух или трёх неблагоприятных социальных факторов. Выводы. У 20,4\% якутов, у 19,1\% эвенов и эвенков, у 13,5\% алтайцев, у 7\% агинских бурят и 29,6\% тувинцев выявлены сочетания двух или трёх неблагоприятных социальных факторов. Эти подростки относятся к группе риска по формированию деструктивного, в том числе, суицидального поведения, и нуждаются в профилактических вмешательствах.

Ключевые слова: подростки, самоубийство, коренные народы Сибири, факторы риска

Проблема суицида среди детей и подростков коренных популяций Сибири стоит довольно остро и не теряет своей актуальности, несмотря на снижение количества самоубийств в целом по России. Начиная с 2004 г. в Российской Федерации произошло уменьшение уровня детско-подростковых самоубийств более чем в 3 раза. Однако в национальных субъектах, по-прежнему, регистрируются высокие значения суицида, в несколько раз превышающие общероссийские показатели $[1,2]$.

Анализ исторических документов свидетельствует о том, что добровольный уход из жизни никогда не являлся способом решения проблем у коренных народов Сибири, а сам факт самоубийства осуждался анимистическим религиозным мировоззрением [3]. И в настоящее время, несмотря на высокие показатели суицида среди коренных народов, большинство молодых людей всё же не демонстрируют суицидальных тенденций. О том, что самоубийства можно предотвращать подчеркивается экспертами ВОЗ в докладе о превенции суицида на глобальном уровне [4]. Для этого должны быть разработаны национальные стратегии предотвращения самоубийств, основан- 
ные на научных знаниях о факторах риска и защитных факторах и на доказательной базе.

Причины суицидального поведения у коренных народов Сибири были раскрыты в наших предыдущих статьях. Они заключаются в смене традиционного образа жизни и последовавшей за ней смене религиозного мировоззрения, утрате ценностей патриархальной семьи, трудностях самореализации и социальноэкономических проблемах [5-7]. У детей и подростков причины суицидального поведения являются следствием общих социальных процессов, происходящих на данном этапе социально-исторического развития общества. В то же время, в отличие от взрослых, причины самоубийств у молодого поколения более конкретны, многие из них связаны с аффилиацией и отсутствием чувства защищённости в близком социальном окружении.

Данной статьей мы открываем цикл научных публикаций, посвящённых факторам риска суицидального поведения у детей и подростков коренных народов Сибири - якутов, эвенов и эвенков, алтайцев, бурят, тувинцев. В представленном материале будут раскрыты социальные факторы риска.

Известно, что одной из главных причин суицида в подростковом возрасте является семейное неблагополучие, около 50\% подростковых самоубийств объясняются семейными факторами [8]. Семейное окружение у подростков, совершивших суицидальную попытку или завершённый суицид, часто характеризуется внутрисемейными конфликтами, низким уровнем родительского тепла и заботы, дефицитом эмоциональных контактов, пренебрежительным отношением к ребёнку и его потребностям [9]. Нередко в семьях подростков, совершивших суицид, присутствуют домашнее насилие и алкоголизация родителей [10]. Негативное влияние факторов социальной среды, пережитое в детском возрасте, может явиться причиной суицидального поведения во взрослом состоянии $[11,12]$.

Причины суицидального поведения у детей и подростков коренных народов аналогичны выше перечисленным. Учёными из Канады показано, что инуиты (эскимосы), совершившие суицид, чаще, чем представители контрольной группы, имели опыт физического и сексуального насилия в детском возрасте [13]. Неблагоприятные детские переживания у коренных американцев - эмоциональное, физиче- ское и сексуальное насилие, физическое и эмоциональное пренебрежение - связаны с многочисленными рисками нарушений поведения, в том числе, суицидальными тенденциями [14].

Исследования последних лет, проведённые в Сибирском регионе, обозначили высокую роль семейных факторов в формировании суицидального поведения у подростков, проживающих в Сибири [15-20]. Анализ суицида у детей и подростков в Иркутской области показал, что молодые люди, совершившие суицид или суицидальную попытку, имели деструктивные формы семейного взаимодействия $(51,8$ и $65,2 \%)$ или патологические типы семейного воспитания (89,2 и 93,5\%) [15]. Около 60\% молодых людей, совершивших завершенный суицид, проживали в малообеспеченных многодетных семьях, в половине семей родители злоупотребляли алкоголем, в каждой второй семье присутствовали моральное и физическое насилие над детьми. Анализ содержания психотравмирующих ситуаций показал, что в половине случаев к суицидальным попыткам приводили семейные конфликты [17]. Рестроспективный анализ случаев детско - подросткового парасуицида, проведённый в Забайкальском крае, выявил семейное неблагополучие у 73\% подростков, в том числе, авторитарный стиль воспитания или эмоциональную депривацию [19]. В исследованиях по изучению причин самоубийств у детей и подростков в Якутии выявлено, что более $60 \%$ семей, в которых воспитывались молодые люди, относились к разряду социально неблагополучных. Около 40\% детей и подростков воспитывались в неполных семьях, около 20\% суицидентов являлись социальными сиротами и воспитывались опекунами или приёмными родителями. В большинстве семей отмечалось насилие над детьми и хроническая алкоголизация родителей. Остальные семьи, в которых были зарегистрированы случаи завершенного суицида, относились к разряду благополучных. Однако мнимое семейное благополучие было лишь внешним фасадом, за которым скрывались эмоциональное отвержение ребёнка, холодность во взаимоотношениях, повышенные моральные требования к ребёнку, двойные стандарты родительского поведения [20].

Ранее нами было показано, что в национальных субъектах Российской Федерации регистрируется значительное количество неблагополучных семей $[21,22]$. Это подтвер- 
ждается данными государственной статистики. Так, в Республике Саха (Якутия) в 2014 году зарегистрировано 3332 семьи, находящихся в трудной жизненной ситуации, и 1423 семьи, находящихся в социально опасном положении; в них воспитываются 6403 и 3066 детей соответственно. В 2014 году в отношении детей было совершено 974 преступления, из них тяжких -62 , особо тяжких - 68, преступлений против половой неприкосновенности - 165. Наибольший рост числа преступлений регистрируется в поселках, где проживает коренное население [23]. В Республике Тыва в 2016 году зарегистрировано 1462 семьи, находящихся в социально опасном положении, в которых воспитываются 3762 детей. В отношении детей было совершено 743 преступления, из них 51 преступление против половой неприкосновенности [24]. В Республике Алтай в 2016 году зарегистрировано 42 семьи, находящихся в социально опасном положении, в них воспитываются 107 детей [25]. Рост преступности в отношении несовершеннолетних зарегистрирован в Агинском Бурятском округе: в 2015 году совершено 160 преступлений в отношении детей и подростков, что на $17 \%$ больше, по сравнению с 2014 годом [26].

В подростковом возрасте, помимо близкого семейного окружения, большое значение приобретают другие социальные факторы, в том числе, внешнее окружение подростка и система межличностных связей. Взаимоотношения со сверстниками и романтические отношения с лицами противоположного пола становятся важными для молодого человека в период личностного становления. В то же время, взрослеющий человек стремится завоевать уважение со стороны значимых взрослых родителей и педагогов. Если возникают проблемы во взаимоотношениях, появляется чувство одиночества, «непонятости», социальная изоляция, - все это оказывает неблагоприятное влияние на неустойчивую самооценку и может стать пусковым механизмом суицидального поведения. Провоцирующими факторами у $34 \%$ подростков, проживающих в Забайкальском крае, явились конфликт с учителем и несчастная любовь [18, 19]. Выявлено, что проблемы в сфере межличностных взаимоотношений, особенно со сверстниками и педагогами, являются наиболее значимыми социальными факторами, ассоциированными с риском суицидального поведения у детей и подростков
[18]. Анализ «кристаллизирующих» факторов самоубийств у подростков Якутии, показал, что «последней каплей», подтолкнувшей молодого человека к суициду, в большинстве случаев явились семейные ссоры и конфликты $(34,1 \%)$, однако у $26,6 \%$ подростков суицид был спровоцирован разрывом отношений с лицами противоположного пола или конфликтом со сверстниками [20].

Ещё одна сторона социального функционирования у молодежи связана с вовлечением в разные подростковые группировки, которые могут оказывать деструктивное влияние. В многочисленных исследованиях, проведённых на популяции американских индейцев, показана роль рискованного и агрессивного поведения в появлении суицидальных наклонностей у подростков. Суицидальный риск резко увеличивается при склонности молодых людей к алкоголизации или употреблению психоактивных веществ [27-29]. К подобным выводам пришли исследователи, изучавшие детскоподростковый суицид и в Сибирском регионе. Показано, что 55\% молодых людей, совершивших суицидальную попытку в Забайкальском крае, употребляли алкоголь, у 40\% отмечались эпизоды бродяжничества [19]. При анализе суицидального поведения у детей и подростков в Иркутской области выявлено, что различные проявления девиантного поведения имелись у $31,9 \%$ подростков, погибших от суицида, и $28,3 \%$ подростков, совершивших покушение. В состоянии алкогольного опьянения находились $27,1 \%$ человек, закончивших жизнь самоубийством, и $30,4 \%$ человек, совершивших суицидальную попытку. Употребление ПАВ зафиксировано у $30,4 \%$ детей и подростков, совершивших завершённый суицид [15].

Таким образом, на сегодняшний день считается доказанным, что к социальным факторам, ассоциированным с риском суицидального поведения у подростков, относятся семейное неблагополучие, нарушения межличностных взаимоотношений и девиантное поведение. Риск суицидального поведения будет выше в неблагоприятной социальной среде, и будет зависеть от кумулятивного влияния негативных воздействий.

Целью настоящего исследования явилась оценка распространённости и выраженности социальных факторов риска, ассоциированных с суицидальным поведением, у подростков коренных популяций Сибири. 
Задачи исследования:

1. Оценить социальное окружение, систему межличностных взаимоотношений и признаки девиантного поведения у подростков разных этнических групп.

2. Изучить распространенность социальных рисков, связанных с семейным неблагополучием, проблемами межличностных взаимоотношений и девиантным поведением.

3. Выявить частоту комбинаций социальных факторов риска у подростков разных популяций.

Объект исследования: подростки шести этнических групп - якуты, эвены, эвенки, алтайцы, агинские буряты и тувинцы - представители коренных популяций Сибири.

Предмет исследования: социальные факторы, ассоциированные с риском суицидального поведения у подростков коренных популяций Сибири.

Материал исследования: социальногигиенические анкеты для подростков.

Методы исследования: метод анонимного анкетирования, социально-гигиенический метод, метод статистического анализа.

\section{Дизайн исследования:}

Мы изучали три группы социальных факторов, ассоциированных с риском суицидального поведения у подростков: I. Группа семейных факторов риска. II. Группа рисков, связанных с системой взаимоотношений. III. Группа рисков, связанных с девиантностью. Каждая группа включала в себя 4 составляющих:

I. Группа семейных факторов риска: 1) материально-бытовые проблемы семьи; 2) проблемы внутрисемейных отношений; 3) наличие конфликтов в семье; 4) алкоголизация родителей.

II. Группа рисков, связанных с системой взаимоотношений: 1) проблемы в отношениях с родителями; 2) проблемы в отношениях с учителями; 3) проблемы в отношениях со сверстниками; 4) проблемы в отношениях с лицами противоположного пола.

III. Группа рисков, связанных с девиантностью: 1) употребление алкоголя; 2) употребление психоактивных веществ (ПАВ); 3) наличие друзей, употребляющих алкоголь или ПАВ; 4) наличие друзей с криминальными наклонностями.

В экспедиционных условиях обследованы подростки, проживающие в четырёх национальных субъектах Российской Федерации.
Три этнические группы (якуты, эвены и эвенки) живут на северных территориях Сибири - в Республике Саха (Якутия). Другие три этнические группы (алтайцы, агинские буряты и тувинцы) живут на южных территориях Сибири, приравненных к районам Крайнего Севера, - в национальных республиках Алтай, Тыва и Агинском Бурятском округе. Обследованием охвачено 30 населённых пунктов: в Республике Саха-Якутия - пос. Депутатский, сёла Казачье, Усть-Куйга, Усть-Янск, Сайылык; Абага, Петропавловск, Эжанцы, Кюпцы, Дабан, Тяня, Кыллах, Токко; в Республике Алтай - пос. Улаган, Кош-Агач, Майма, сёла Акташ, Чибит, Бельтир, Мухор-Тархата, г. Горноалтайск; в Агинском Бурятском округе - пос. Агинское, Орловский, Новоорловский, Могойтуй; в Республике Тыва - пос. Чаа-Холь, Хандагайты, Тээли, Хемчиг, Торгалык, г. Кызыл.

Обследование подростков проводилось в общеобразовательных школах. Методом сплошной выборки обследованы учащиеся 1011 классов, из них: якутов 181 (83 мальчика, 98 девочек), эвенов и эвенков - 63 (19 мальчиков, 44 девочки), алтайцев - 103 (40 мальчиков, 63 девочки), бурят - 228 (98 мальчиков, 130 девочек), тувинцев - 206 (79 мальчиков, 127 девочек). Всего обследовано 781 человек, из них 319 мальчиков и 462 девочки, средний возраст составил 16,5 лет. Критерии включения в исследование определялись принадлежностью к одной из вышеперечисленных национальностей.

При проведении исследования использовалась специально разработанная социальногигиеническая анкета, которая включала в себя утверждения, относящиеся к трём группам социальных факторов (12 утверждений) и 4 дополнительных утверждения уточняющего характера. Каждому утверждению соответствовало три ответа («верно», «не отрицаю, что это так» и «не верно»), которые подросток должен был отметить как наиболее подходящий. Утверждения кодировались как «0», «1» или «2». К анкете предъявлялись следующие требования: краткость и лаконичность формулировок, соответствие формулировок понятийному аппарату детей и подростков коренных этносов, отсутствие двусмысленности интерпретаций.

Обработка данных осуществлялась в три этапа. 
Социальный статус у подростков разных этнических групп (\%)

Таблица 1

\begin{tabular}{|c|c|c|c|c|c|}
\hline Социальные факторы & $\begin{array}{c}1 . \\
\text { Якуты } \\
(\mathrm{n}=181)\end{array}$ & $\begin{array}{c}2 . \\
\text { Эвены, } \\
\text { эвенки } \\
(\mathrm{n}=63) \\
\end{array}$ & $\begin{array}{c}3 . \\
\text { Алтайцы } \\
(\mathrm{n}=103)\end{array}$ & $\begin{array}{c}4 . \\
\text { Агинские } \\
\text { буряты } \\
(\mathrm{n}=228) \\
\end{array}$ & $\begin{array}{c}5 . \\
\text { Тувинцы } \\
(\mathrm{n}=206)\end{array}$ \\
\hline \multicolumn{6}{|l|}{$\begin{array}{l}\text { I. Семейное окружение } \\
\text { Материально-бытовые условия: }\end{array}$} \\
\hline Хорошие & 72,9 & 77,8 & 91,3 & 91,2 & 77,2 \\
\hline Удовлетворительные & 26,5 & 22,2 & 8,7 & 8,8 & 19,9 \\
\hline Плохие & 0,5 & 0 & 0 & 0 & 2,9 \\
\hline \multicolumn{6}{|l|}{ Внутрисемейные отношения: } \\
\hline Хорошие, теплые, дружеские & 70,2 & 74,6 & 78,6 & 81,2 & 84,9 \\
\hline Удовлетворительные & 27,1 & 22,2 & 21,4 & 17,9 & 12,1 \\
\hline Плохие & 2,7 & 3,2 & 0 & 0,9 & 2,9 \\
\hline \multicolumn{6}{|l|}{ Конфликты в семье: } \\
\hline Отсутствуют & 22,6 & 22,2 & 30,1 & 27,2 & 24,7 \\
\hline Редкие, реже 1 раза/месяц & 55,8 & 68,2 & 54,4 & 58,8 & 58,3 \\
\hline Чаще 1 раза/месяц & 15,5 & 6,4 & 13,6 & 11,8 & 11,7 \\
\hline Каждую неделю & 6,1 & 3,2 & 1,9 & 2,2 & 5,3 \\
\hline \multicolumn{6}{|l|}{ Алкоголизация близких родственников: } \\
\hline В семье таких нет & 74,6 & 76,2 & 85,4 & 90,3 & 78,6 \\
\hline Не отрицаю, что есть такие & 17,7 & 12,7 & 11,7 & 8,7 & 17,5 \\
\hline $\begin{array}{l}\text { В семье есть алкоголики } \\
\text { II. Система отношений }\end{array}$ & 7,7 & 11,1 & 2,9 & 0,9 & 3,9 \\
\hline \multicolumn{6}{|l|}{ Отношения с родителями: } \\
\hline Хорошие, дружеские & 64,6 & 68,3 & 82,5 & 83,8 & 86,4 \\
\hline Удовлетворительные & 27,1 & 20,6 & 17,5 & 14,0 & 11,7 \\
\hline Отсутствует взаимопонимание: & 8,3 & 11,1 & 0 & 2,2 & 1,9 \\
\hline \multicolumn{6}{|l|}{ Отношения с учителями } \\
\hline Хорошие, доверительные & 56,9 & 58,7 & 71,8 & 62,3 & 76,7 \\
\hline Удовлетворительные & 39,2 & 33,3 & 28,2 & 35,1 & 22,8 \\
\hline Плохие & 3,9 & 7,9 & 0 & 2,6 & 0,5 \\
\hline \multicolumn{6}{|l|}{ Отношения со сверстниками: } \\
\hline Хорошие, дружеские & 80,7 & 73,0 & 86,4 & 83,3 & 79,6 \\
\hline Удовлетворительные & 17,7 & 25,4 & 13,6 & 14,9 & 18,4 \\
\hline Плохие & 1,6 & 1,6 & 0 & 1,7 & 1,9 \\
\hline \multicolumn{6}{|l|}{ Отношения с противоположным полом: } \\
\hline Проблем не имею & 84,5 & 84,1 & 87,4 & 90,3 & 78,6 \\
\hline Не отрицаю, что имею проблемы & 13,3 & 11,1 & 11,7 & 9,2 & 16,0 \\
\hline $\begin{array}{l}\text { Имеются проблемы } \\
\text { III. Девиантность }\end{array}$ & 2,2 & 4,8 & 0,9 & 0,4 & 5,3 \\
\hline \multicolumn{6}{|l|}{ Отношение к алкоголю: } \\
\hline Негативное & 74,0 & 63,5 & 92,2 & 80,3 & 82,5 \\
\hline Не отрицаю, что употребляю алкоголь & 25,4 & 30,1 & 7,8 & 17,5 & 15,0 \\
\hline \multirow{2}{*}{\multicolumn{6}{|c|}{ Отношение к ПАВ: }} \\
\hline & & & & & \\
\hline Негативное & 98,3 & 100 & 100 & 99,6 & 94,2 \\
\hline Не отрицаю, что употребляю ПАВ & 0,6 & 0 & 0 & 0,4 & 4,4 \\
\hline Употребляю ПАВ & 1,1 & 0 & 0 & 0 & 1,4 \\
\hline \multicolumn{6}{|l|}{ Друзья, употребляющие алкоголь или ПАВ: } \\
\hline Нет таких друзей & 38,1 & 30,2 & 57,3 & 56,6 & 66,0 \\
\hline Не отрицаю, что имею таких друзей & 44,2 & 55,5 & 40,8 & 38,6 & 24,7 \\
\hline Есть такие друзья & 17,7 & 14,3 & 1,9 & 4,8 & 9,2 \\
\hline \multicolumn{6}{|l|}{ Друзья с криминальными наклонностями: } \\
\hline Нет таких друзей & 70,2 & 73,0 & 92,2 & 85,1 & 74,3 \\
\hline Не отрицаю, что имею таких друзей & 24,9 & 22,2 & 7,8 & 12,7 & 18,9 \\
\hline Есть такие друзья & 4,9 & 4,8 & 0 & 2,2 & 6,8 \\
\hline
\end{tabular}


На первом этапе проводилась оценка социального статуса подростков, включая семейное окружение, систему межличностных взаимоотношений и признаки девиантности. На втором этапе мы оценивали количество социальных рисков, вызванных семейными проблемами, проблемами взаимоотношений и девиантностью (от 0 - полное отсутствие риска, до 4 максимальное количество рисков). На третьем этапе проводилась оценка комбинаций социальных факторов риска по всем трём блокам (от 0 - полное отсутствие социальных факторов риска, до 3 - максимальное сочетание социальных факторов риска) и их частота.

Статистическая обработка полученных результатов проводилась с использованием пакета прикладных программ STATISTICA for Window, Version X. Для анализа вида распределения количественных данных мы применяли критерий Шапиро-Уилка. Статистический анализ бинарных признаков проводился с подсчётом относительной частоты (\%). Статистический анализ количественных признаков проводился с подсчётом среднего арифметического значения (М) и стандартной ошибки среднего значения (m). Сравнение двух несвязанных групп проводилось с использованием $\mathrm{t}-$ критерия для равенства средних. Сравнение групп по качественному бинарному признаку проводилось с помощью $\chi^{2}$. Для исследования силы взаимосвязи показателей вычислялся коэффициент парной корреляции Спирмена (r). Величина уровня значимости различий принималась при $\mathrm{p}=0,05$, то есть при ошибке $5 \%$.

Результаты и обсуждение.

Анализ социального статуса у подростков разных этнических групп показал, что большинство подростков расценивают близкое семейное окружение как благополучное. От 77,2 до $91,3 \%$ человек считают, что в их семьях хорошие материально-бытовые условия, 70,2$84,9 \%$ человек высказались о том, что у них в семье «хорошие, теплые и дружеские» отношения, у 74,6-90,3\% человек родители ведут трезвый образ жизни. В таких семьях отмечается благоприятный психологический климат, отсутствуют конфликты, присутствует взаимопонимание между членами семьи (табл. 1).

В то же время, около 30\% подростков воспитываются в неблагополучных семьях, в которых материально-бытовые условия часто не удовлетворяют нужды и потребности молодого поколения, а родители злоупотребляют алко- голем. Материально-бытовые условия семьи назвали плохими или удовлетворительными $27 \%$ якутов и $22,2 \%$ эвенов и эвенков, $8,7 \%$ алтайцев, $8,8 \%$ агинских бурят и 22,8 тувинцев. Внутрисемейные отношения считают плохими или удовлетворительными 29,8\% якутов, 25,4\% эвенов и эвенков, $21,4 \%$ алтайцев, $18,8 \%$ бурят и $15 \%$ тувинцев. Алкоголизация родителей отмечается в семьях у $25,4 \%$ якутских подростков, $23,8 \%$ эвенских и эвенкийских, у $14,6 \%$ алтайских, у 9,7\% бурятских и $21,4 \%$ тувинских подростков. В таких семьях присутствует неблагоприятный психологический климат, а между членами семьи отмечаются напряжённые отношения, конфликты. Причинами внутрисемейных конфликтов, по мнению подростков, чаще являются детскородительские отношения: у $56,8 \%$ якутов, $61,8 \%$ эвенов и эвенков, 56,9\% алтайцев, 59\% агинских бурят. Алкоголизацию родителей как причину конфликта отмечают $16,1 \%$ якутских, $20 \%$ эвенских и эвенкийских $12,3 \%$ алтайских, $12,0 \%$ бурятских и $24,7 \%$ тувинских подростков.

Анализ системы взаимоотношений показал, что большинство подростков не имеют проблем в общении. От 64,6 до 86,4\% молодых людей считают, что у них «хорошие и дружеские» отношения с родителями. От 56,9 до $76,7 \%$ подростков считают, что у них «хорошие и доверительные» отношения с учителями. Отношения со сверстниками считают «хорошими и дружескими» от 73 до $86,4 \%$ человек. Не имеют проблем в отношениях с представителями противоположного пола от 84,1 до $90,3 \%$ подростков. Независимо от этнической принадлежности и места проживания, подростки имеют лучшие отношения со сверстниками, и худшие - с педагогами. Ряд молодых людей испытывают трудности в общении, в том числе, с родителями - $13,6-35,4 \%$; со сверстниками - 13,6-27\%; с лицами противоположного пола $-9,7-21,4 \%$; с учителями 23,3-43,1\%.

Корреляционный анализ выявил, что неблагополучное семейное окружение, алкоголизация родителей и конфликты в семье связаны с нарушением всей системы межличностных взаимоотношений у подростков. В первую очередь, это касается отношений с родителями $(\mathrm{p}<0,01)$, но также - со сверстниками, учителями и представителями противоположного пола (табл. 2). 
Корреляции семейных факторов риска с системой отношений и девиантностью

\begin{tabular}{|c|c|c|c|c|}
\hline Этнические группы и факторы & $\begin{array}{c}\text { Материально- } \\
\text { бытовые } \\
\text { условия }\end{array}$ & $\begin{array}{c}\text { Отношения } \\
\text { в семье }\end{array}$ & $\begin{array}{c}\text { Наличие } \\
\text { конфликтов } \\
\text { в семье }\end{array}$ & $\begin{array}{c}\text { Алкоголизация } \\
\text { родителей }\end{array}$ \\
\hline \multicolumn{5}{|l|}{ Якутьл } \\
\hline отношения с родителями & $0,23 * *$ & $0,47 * *$ & $0,32 * *$ & $0,17 *$ \\
\hline отношения с педагогами & $0,23 * *$ & 0,02 & $0,19 *$ & 0,01 \\
\hline отношения со сверстниками & $0,16 *$ & 0,13 & 0,06 & 0,09 \\
\hline отношения с противоположным полом & $0,19 *$ & $0,15 *$ & $0,28 * *$ & 0,09 \\
\hline друзья, злоупотребляющие алкоголем & 0,06 & 0,05 & $0,18 *$ & $0,15 *$ \\
\hline криминальные друзья & 0,08 & 0,10 & 0,11 & 0,09 \\
\hline отношение к алкоголю & 0,14 & 0,12 & $0,31 * *$ & 0,13 \\
\hline отношение к ПАВ & 0,02 & $-0,08$ & 0,06 & 0,16 \\
\hline \multicolumn{5}{|l|}{ Эвены, эвенки } \\
\hline отношения с родителями & $0,41 * *$ & $0,54 * *$ & $0,39 * *$ & $0,29 *$ \\
\hline отношения с педагогами & 0,11 & $0,28 *$ & 0,17 & 0,05 \\
\hline отношения со сверстниками & $0,29 *$ & $0,32 *$ & 0,14 & 0,18 \\
\hline отношения с противоположным полом & 0,01 & 0,04 & 0,17 & 0,08 \\
\hline друзья, злоупотребляющие алкоголем & 0,78 & 0,11 & $0,32 * *$ & 0,2 \\
\hline криминальные друзья & 0,17 & 0,06 & 0,06 & 0,06 \\
\hline отношение к алкоголю & 0,17 & 0,13 & 0,17 & 0,08 \\
\hline отношение к ПАВ & 0,0 & 0,0 & 0,0 & 0,0 \\
\hline \multicolumn{5}{|l|}{ Алтайu̧ь } \\
\hline отношения с родителями & 0,19 & $0,20 *$ & $0,29 * *$ & 0,01 \\
\hline отношения с педагогами & 0,02 & 0,14 & 0,06 & 0,01 \\
\hline отношения со сверстниками & 0,04 & $0,20 *$ & 0,09 & 0,12 \\
\hline отношения с противоположным полом & 0,19 & $0,23 *$ & $0,24 *$ & $0,34 * *$ \\
\hline друзья, злоупотребляющие алкоголем & 0,17 & 0,11 & 0,08 & 0,12 \\
\hline криминальные друзья & $0,24 *$ & 0,16 & 0,13 & 0,04 \\
\hline отношение к алкоголю & 0,19 & $0,22 *$ & $0,24 *$ & $0,34 * *$ \\
\hline отношение к ПАВ & 0,0 & 0,0 & 0,0 & 0,0 \\
\hline \multicolumn{5}{|l|}{ Бурять } \\
\hline отношения с родителями & 0,12 & $0,58 * *$ & $0,32 * *$ & 0,05 \\
\hline отношения с педагогами & 0,11 & 0,01 & 0,04 & 0,04 \\
\hline отношения со сверстниками & $0,16 *$ & $0,18 * *$ & $0,17 * *$ & $0,21 * *$ \\
\hline отношения с противоположным полом & $0,16 *$ & $0,15 *$ & $0,17 * *$ & $0,19 * *$ \\
\hline друзья, злоупотребляющие алкоголем & 0,01 & 0,05 & $0,18 * *$ & 0,13 \\
\hline криминальные друзья & 0,08 & 0,42 & 0,05 & 0,11 \\
\hline отношение к алкоголю & 0,05 & 0,06 & 0,14 & 0,03 \\
\hline отношение к ПАВ & $-0,02$ & $-0,03$ & $-0,09$ & $-0,02$ \\
\hline \multicolumn{5}{|l|}{ Тувиниьы } \\
\hline отношения с родителями & $0,29 * *$ & $0,48 * *$ & 0,26 & 0,13 \\
\hline отношения с педагогами & $0,32 * *$ & $0,18 * *$ & 0,03 & 0,03 \\
\hline отношения со сверстниками & $0,14 *$ & $0,19 * *$ & 0,03 & 0,01 \\
\hline отношения с противоположным полом & 0,05 & 0,05 & 0,03 & $0,16 *$ \\
\hline друзья, злоупотребляющие алкоголем & 0,06 & $0,28 * *$ & $0,15 *$ & $0,23 * *$ \\
\hline криминальные друзья & 0,01 & $0,17 *$ & 0,07 & 0,08 \\
\hline отношение к алкоголю & 0,04 & 0,09 & 0,13 & $0,19 * *$ \\
\hline отношение к ПАВ & 0,00 & 0,05 & 0,04 & 0,13 \\
\hline
\end{tabular}

Примечание: * $\mathrm{p}<0,05 ; * * \mathrm{p}<0,01$

При оценке девиантности отмечается, что большинство молодых людей негативно относятся к употреблению психоактивных веществ (ПАВ), о чём заявили от 98,3 до $100 \%$ человек. Об отрицательном отношении к алкоголю высказались от 63,5 до $92,2 \%$ подростков. Не имеют друзей, употребляющих алкоголь или ПАВ, от 30,2 до $66 \%$ подростков. Не имеют друзей с криминальными наклонностями от 70,2 до 92,2\% опрошенных.

В то же время, у части молодых людей обнаруживаются те или иные проявления девиа- 
нтного поведения. О том, что они употребляют алкоголь или не отрицают этого факта, заявили $26 \%$ якутов, $36,6 \%$ эвенов и эвенков, $7,8 \%$ алтайцев, $19,7 \%$ бурят и $17,4 \%$ тувинцев. О том, что они имеют друзей, употребляющих алкоголь или ПАВ, высказались прямо 14,3\% эвенов и эвенков и $17,7 \%$ якутов, еще $55,5 \%$ эвенов и эвенков и 44,2\% якутов не отрицают данного факта. Таких друзей имеют в своем окружении 42,7\% алтайцев, 43,4\% агинских бурят и $34 \%$ тувинцев. Друзей с криминальными наклонностями имеют $29,8 \%$ якутов, $27 \%$ эвенов и эвенков, 7,8\% алтайцев, $14,9 \%$ агинских бурят и $25,7 \%$ тувинцев.

Корреляционный анализ показал, что склонность к употреблению алкоголя у подростков разных этнических групп связана с разными семейными рисками: у якутов - с наличием конфликтных отношений в семье $(\mathrm{r}=0,31 ; \mathrm{p}<0,01)$, а у алтайцев и тувинцев - c алкоголизацией родителей $(\mathrm{r}=0,34 ; \mathrm{p}<0,01$ и $\mathrm{r}=0,19 ; \mathrm{p}<0,01$, соответственно).

Таким образом, анализ социального статуса у подростков коренных популяций Сибири показал, что большинство молодых людей имеют благополучное семейное окружение, не имеют проблем в общении с родителями, учителями, сверстниками и лицами противоположного пола, отрицательно относятся к алкоголю и ПАВ, не имеют в своем окружении друзей с криминальными наклонностями.

Вместе с тем, часть подростков имеют те или иные риски, ассоциированные с суицидальным поведением (табл. 3).

Так, семейные факторы риска, связанные с материально-бытовыми проблемами семьи, отмечаются у 8,7-27,1\%; связанные с проблемами внутрисемейных отношений у 15,0 $29,8 \%$; с наличием конфликтов в семье у $9,6-$ $21,6 \%$; с алкоголизацией родителей у 9,6$25,5 \%$ подростков. Риски системы взаимоотношений, связанные с проблемами в отношениях с родителями, выявлены у $13,6-35,4 \%$ молодых людей; с проблемами в отношениях с учителями у $23,3-43,1 \%$; с проблемами в отношениях со сверстниками у $13,6-27,0$; с проблемами в отношениях с лицами противоположного пола у 9,6-21,3\% подростков.

Таблица 3

Частота социальных рисков, ассоциированных с суицидальным поведением (\%)

\begin{tabular}{|c|c|c|c|c|c|}
\hline $\begin{array}{c}\text { Социальные факторы риска } \\
\text { и их составляющие }\end{array}$ & $\begin{array}{c}1 . \\
\text { Якуты } \\
(\mathrm{n}=181)\end{array}$ & $\begin{array}{c}2 . \\
\text { Эвены, } \\
\text { эвенки } \\
(\mathrm{n}=63)\end{array}$ & $\begin{array}{l}3 . \\
\text { Алтайцы } \\
(\mathrm{n}=103)\end{array}$ & $\begin{array}{l}4 . \\
\text { Агинские } \\
\text { буряты } \\
(\mathrm{n}=228)\end{array}$ & $\begin{array}{l}5 . \\
\text { Тувинцы } \\
(\mathrm{n}=206)\end{array}$ \\
\hline I. Семейные факторы риска & & & & & \\
\hline 1) материально-бытовые проблемы семьи & 27,1 & 22,2 & 8,7 & 8,8 & 22,8 \\
\hline 2) проблемы внутрисемейных отношений & 29,8 & 25,4 & 21,4 & 18,8 & 15,0 \\
\hline 3) наличие конфликтов в семье & 21,6 & 9,6 & 15,5 & 14,0 & 17,0 \\
\hline 4) алкоголизация родителей & 25,5 & 23,8 & 14,6 & 9,6 & 21,4 \\
\hline \multicolumn{6}{|c|}{$\begin{array}{l}p^{*} \text { 1) } 1-3<0,001 ; 1-4<0,001 ; 2-3<0,001 ; 2-4<0,001 ; 3-5=0,003 ; 4-5<0,001 \\
\text { 3) } 1-2=0,03 ; 1-4<0,001 ; \\
\text { 4) } 1-3=0,03 ; 1-4<0,001 ; 2-4=0,003 ; 4-5<0,001\end{array}$} \\
\hline II. Риски системы взаимоотномений & & & & & \\
\hline 1) проблемы в отношениях с родителями & 35,4 & 31,7 & 17,5 & 16,2 & 13,6 \\
\hline 2) проблемы в отношениях с учителями & 43,1 & 41,2 & 28,2 & 37,7 & 23,3 \\
\hline 3) проблемы в отношениях со сверстниками & 19,3 & 27 & 13,6 & 16,6 & 20,3 \\
\hline 3) проблемы в отношениях с противоположным полом & 15,5 & 15,9 & 12,6 & 9,6 & 21,3 \\
\hline \multicolumn{6}{|c|}{$\begin{array}{l}p^{*} \text { 1) } 1-3=0,001 ; 1-4<0,001 ; 1-5<0,001 ; 2-3=0,03 ; 2-4=0,006 ; 2-5=0,001 \\
\text { 2) } 1-3=0,01 ; 1-5<0,001 ; 2-5<0,001 ; \\
\text { 3) } 2-3=0,03 ; \\
\text { 4) } 4-5<0,001\end{array}$} \\
\hline III. Риски девиантности & & & & & \\
\hline 1) употребление алкоголя & 26 & 36,6 & 7,8 & 19,7 & 17,4 \\
\hline 2) употребление ПАВ & 1,7 & 0 & 0 & 0,4 & 5,8 \\
\hline 3) наличие друзей, употребляющих алкоголь / ПАВ & 61,9 & 69,8 & 42,7 & 43,4 & 33,9 \\
\hline 4) наличие друзей, криминальными наклонностями & 29,8 & 27 & 7,8 & 14,9 & 25,7 \\
\hline \multicolumn{6}{|c|}{$\begin{array}{l}\text { * 1) } 1-3<0,001 ; 2-3<0,001 ; 2-4=0,002 ; 3-4=0,01 ; \\
\text { 3) } 1-3=0,002 ; 1-4<0,001 ; 1-5<0,001 ; 2-3<0,001 ; 2-4<0,001 ; 2-5<0,001 \\
\text { 4) } 1-3<0,001 ; 1-4<0,001 ; 2-3<0,001 ; 2-4=0,03 ; 3-5<0,001 ; 4-5=0,005\end{array}$} \\
\hline
\end{tabular}


Риски девиантности, связанные с употреблением алкоголя, выявлены у 7,8-36,6\%; с употреблением ПАВ у $0-5,8 \%$; с наличием друзей, употребляющих алкоголь или ПАВ у 33,9$69,8 \%$; с наличием друзей, имеющих криминальные наклонности, у 7,8-29,8\% подростков.

Сравнительный анализ факторов риска показал, что наиболее неблагоприятная ситуация отмечается в северных районах Сибири. В семьях у подростков якутской, эвенской и эвенкийской национальностей материальнобытовые проблемы встречаются в 2,5 раза чаще, чем в семьях алтайцев и агинских бурят $(\mathrm{p}<0,001)$. Алкоголизация у родителей подростков этих же этнических популяций встречается в 1,5-2,5 раза чаще, чем у родителей алтайских и бурятских подростков $(\mathrm{p}<0,05)$. В семьях юношей и девушек тувинской национальности материально-бытовые проблемы и алкоголизация родителей отмечаются также часто, как и у подростков, проживающих на севере, и чаще, чем у алтайцев и агинских бурят $(\mathrm{p}<0,001)$.

Проблемы в отношениях с родителями у подростков, проживающих в северных районах, выявляются в 2-2,5 чаще, по сравнению с алтайцами, агинскими бурятами и тувинцами $(\mathrm{p}<0,05)$. Проблемы в отношениях с лицами противоположного пола чаще отмечаются у тувинцев, особенно, в сравнении с агинскими бурятами $(\mathrm{p}<0,001)$.
Риски девиантности у лиц, проживающих в северных районах Сибири, в несколько раз превышают показатели у подростков, проживающих в южных районах. Так, у якутов, эвенов и эвенков частота употребления алкоголя от 1,5 до 4,5 раз выше, чем у алтайцев, бурят и тувинцев $(\mathrm{p}<0,001)$, а друзья, употребляющие алкоголь или ПАВ, встречаются в 1,5-2 раза чаще. Наличие друзей с криминальными наклонностями с одинаковой частотой встречаются у якутов, эвенков, эвенов и тувинцев, что в 1,8 раз чаще, чем у агинских бурят, и 3,5 раз чаще, чем у алтайцев $(\mathrm{p}<0,05)$.

Для оценки выраженности социальных факторов риска мы сравнили среднее значение четырех составляющих $(\mathrm{M} \pm \mathrm{m})$ в каждой из трёх групп (рис. 1). Сравнительный анализ у подростков, проживающих на разных территориях, показал, что средние значения семейных факторов риска минимально выражены у агинских бурят $(0,5 \pm 0,06 ; \mathrm{p}<0,001)$, и максимально у алтайцев $(1,1 \pm 0,09)$ и тувинцев $(1,1 \pm 0,06)$.

Средние значения рисков, связанных с системой отношений и девиантностью, показывают территориальные различия с бо̀льшей выраженностью их в северных районах. Среднее значение рисков, связанных с проблемами взаимоотношений выше у якутов $(1,1 \pm 0,08$; $\mathrm{p}=0,001)$, эвенов и эвенков $(1,1 \pm 0,12 ; \mathrm{p}<0,05)$ и ниже у алтайцев $(0,7 \pm 0,09)$, у агинских бурят $(0,8 \pm 0,06)$ и у тувинцев $(0,8 \pm 0,07)$.

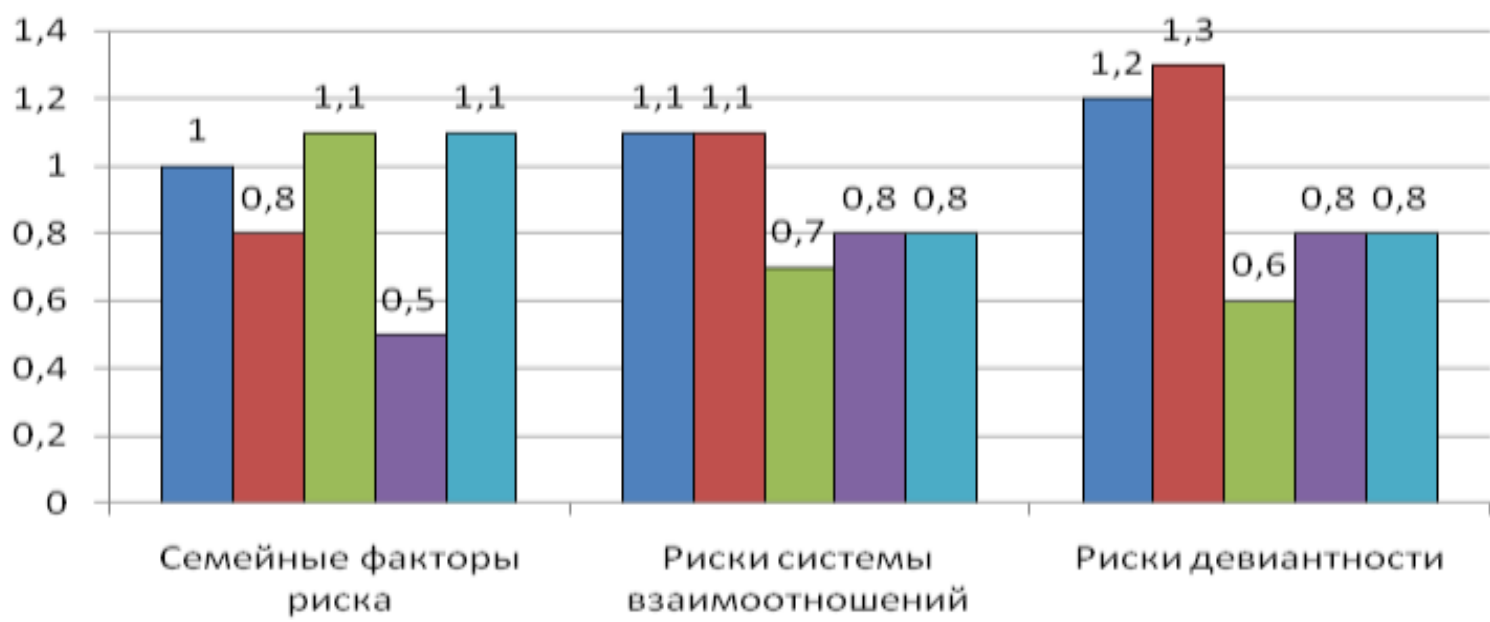

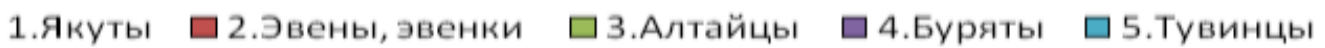

Примечание: $\mathrm{t}-$ критерий для равенства средних

Для семейных рисков: $1-4<0,001 ; 1-5<0,001 ; 2-4=0,04 ; 2-5<0,001 ; 3-4<0,001 ; 4-5<0,001$

Для рисков взаимоотношений: $1-3=0,001 ; 1-4=0,001 ; 1-5=0,001 ; 2-3=0,009 ; 2-4=0,02 ; 2-5=0,01$

Для рисков девиантности: $1-3<0,001 ; 1-4<0,001 ; 1-5=0,001 ; 2-3<0,001 ; 2-4<0,001 ; 2-5=0,001 ; 3-5=0,01$

Puc. 1. Среднее значение количества рисков у подростков разных этнических групп (М). 
Среднее значение рисков девиантного поведения выше у якутов $(1,2 \pm 0,07 ; \mathrm{p} \leq 0,001)$, эвенов и эвенков $(1,3 \pm 0,12 ; \mathrm{p} \leq 0,001)$ и ниже у алтайцев $(0,6 \pm 0,07), \quad$ у агинских бурят $(0,8 \pm 0,06)$ и у тувинцев $(0,8 \pm 0,07)$.

Известно, что суицидальное поведение определяется совокупностью факторов, влияние которых, как правило, взаимосвязано и кумулятивно увеличивает риск суицида. Помимо социальных факторов, в формировании суицидального поведения у подростков участвуют и другие, в том числе, индивидуальнопсихологические особенности, наличие и выраженность дополнительных стрессов, стиль поведения в ситуации фрустрации, когнитивный компонент, этнокультурные факторы риска. На популяции американских индейцев доказано, что при наличии четырёх и более неблагоприятных факторов значительно повышается риск самоубийства, при этом каждый дополнительный фактор увеличивает шанс попытки суицида на $37 \%$ [14]. Понятно, что влияние социальных факторов риска также производит кумулятивный эффект. Поэтому мы оценили частоту комбинаций негативных социальных влияний (рис. 2).

Анализ частоты сочетаний социальных факторов риска показал, что от 70,3 до $92,9 \%$ подростков либо не имеют негативных социальных влияний (0 факторов), либо у них регистрируется всего один негативный социальный фактор. Наиболее благоприятная социальная ситуация отмечается у подростков агинских бурят, подавляющее большинство из которых имеют благополучное социальное окружение. Наши данные согласуются с результатами других исследований, в которых было показано, что у подростков агинских бурят, совершивших суицид или суицидальную попытку, реже, чем у подростков славянских национальностей, обнаруживались неблагополучное микросоциальное окружение и алкоголизация [18].

Сочетания двух или трех социальных факторов выявлены у 29,6\% тувинцев, у 20,4\% якутов, у 19,1\% эвенов и эвенков, у 13,5\% алтайцев и у 7\% агинских бурят. Эти подростки относятся в группу риска по формированию деструктивного, в том числе, суицидального поведения, одна из главных причин которого связана с социальным неблагополучием.

\section{Заключение.}

Целью настоящего исследования явилась оценка распространенности и выраженности социальных факторов риска, ассоциированных с суицидальным поведением, у подростков коренных популяций Сибири. Были изучены три группы факторов: семейные факторы; риски, связанные с системой взаимоотношений; риски девиантности.

На первом этапе оценивался социальный статус подростков, включая близкое семейное окружение, систему межличностных взаимоотношений и признаки девиантного поведения.

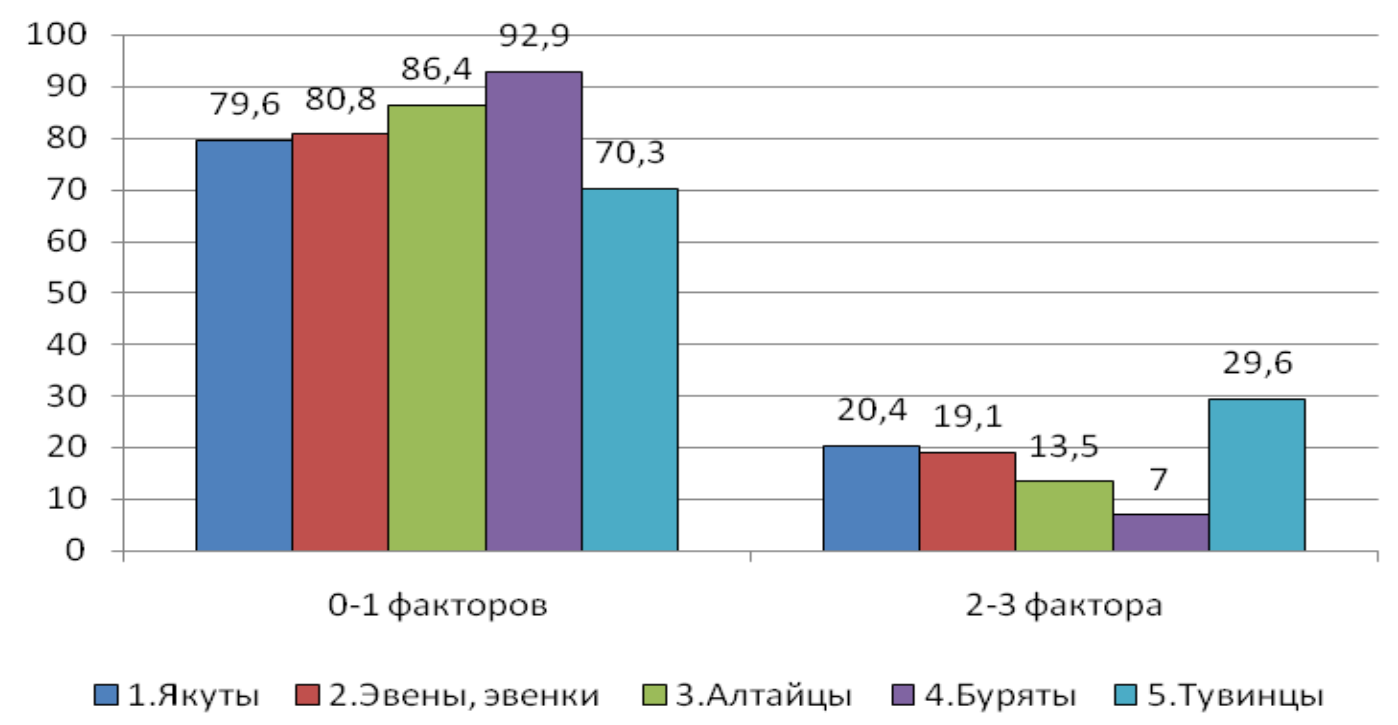

Примечание: Статистическая значимость различий $\left(\chi^{2}\right)$ :

$1-4<0,001 ; 1-5=0,04 ; 2-4=0,004 ; 3-5=0,002 ; 4-5<0,001$

Puc. 2. Частота сочетанных факторов риска у подростков разных этнических групп (\%). 
На втором этапе были выявлены риски, связанные с семейным неблагополучием, проблемами межличностных взаимоотношений и девиантным поведением. На третьем этапе была изучена частота рисков и их комбинаций.

Анализ социального статуса у подростков коренных популяций Сибири показал, что большинство молодых людей имеют благополучное семейное окружение, не имеют проблем в общении, отрицательно относятся к алкоголю и ПАВ, не имеют в своем окружении друзей с криминальными наклонностями.

В то же время, у ряда подростков выявлены те или иные риски, связанные с неблагоприятными социальными факторами. Семейные риски имеют от 7,8 до 29,8\% молодых людей. В том числе, материально-бытовые проблемы в семье отмечаются у 8,7-27,1\% подростков; проблемы внутрисемейных отношений у 15,0-29,8\%; внутрисемейные конфликты у 9,6-21,6\% подростков; у 9,6-25,5\% молодых людей родители злоупотребляют алкоголем.

Риски, связанные с системой взаимоотношений, имеют от 9,6 до 43,1\% подростков. В том числе, проблемы в отношениях с родителями отмечаются у 13,6-35,4\% молодых людей; проблемы в отношениях с учителями у $23,3-43,1 \%$; проблемы в отношениях со сверстниками у 13,6-27,0; проблемы с противоположным полом у 9,6-21,3\% подростков. Независимо от этнической принадлежности и места проживания, подростки имеют лучшие отношения со сверстниками, и худшие - с педагогами.

Риски девиантности имеют от 7,8 до $69,8 \%$ подростков. В том числе, употребляют алкоголь от 7,8 до $36,6 \%$ человек; от 33,9 до $69,8 \%$ подростков имеют в своем окружении друзей, употребляющих алкоголь или ПАВ; от 7,8 до $29,8 \%$ подростков имеют друзей с криминальными наклонностями.

Корреляционный анализ выявил зависимость семейных факторов риска с нарушением всей системы межличностных взаимоотношений. В первую очередь, это касается отношений с родителями $(\mathrm{p}<0,01)$, но также, отношений со сверстниками, учителями и представителями противоположного пола $(\mathrm{p}<0,05)$. Выявлено, что склонность к употреблению алкоголя у подростков разных этнических групп связана с разными семейными рисками: у якутов - с наличием конфликтных отношений в семье $(\mathrm{r}=0,31 ; \mathrm{p}<0,01)$, а у алтайцев и тувинцев
- c алкоголизацией родителей $(\mathrm{r}=0,34 ; \mathrm{p}<0,01$ и $\mathrm{r}=0,19 ; \mathrm{p}<0,01$, соответственно). Этот факт требует дальнейшего изучения и объяснения.

Сравнительный анализ факторов риска в зависимости от территории проживания показал, что наиболее неблагоприятная ситуация отмечается в северных районах Сибири. В семьях у подростков якутской, эвенской и эвенкийской национальностей материальнобытовые проблемы встречаются в 2,5 раза, а алкоголизация у родителей в 1,5-2,5 раза чаще, чем в семьях у алтайских и бурятских подростков $(\mathrm{p}<0,05)$. У подростков, проживающих в северных районах, в 2-2,5 чаще выявляются проблемы в отношениях с родителями, по сравнению с алтайцами, бурятами и тувинцами $(\mathrm{p}<0,05)$. Якуты, эвены и эвенки употребляют алкоголь в 1,5-4,5 раза чаще, чем алтайцы, буряты и тувинцы $(\mathrm{p}<0,001)$. Друзья, употребляющие алкоголь или ПАВ, у подростков, проживающих на северных территориях, встречаются в 1,5-2 раза чаще, чем у подростков, живущих в южных районах Сибири. В семьях подростков тувинской национальности материально-бытовые проблемы и алкоголизация родителей отмечаются также часто, как и у подростков, проживающих на севере.

Известно, что влияние социальных факторов риска производит кумулятивный эффект, поэтому мы оценили частоту комбинаций среди всех трёх групп социальных факторов. Анализ частоты комбинированных факторов риска показал, что от 70,3 до 92,9\% подростков либо не имеют негативных социальных влияний (0 факторов), либо у них регистрируется всего один негативный фактор. Самая благоприятная социальная ситуация отмечается у агинских бурят, подавляющее большинство из которых имеют благополучное социальное окружение.

Сочетания двух или трёх неблагоприятных факторов выявлены у 20,4\% якутов, у $19,1 \%$ эвенов и эвенков, у 13,5\% алтайцев, у 7\% агинских бурят и $29,6 \%$ тувинцев. При том, что отдельные социальные риски чаще представлены у подростков, проживающих в северных территориях Сибири, их сочетания чаще встречаются у тувинских подростков $(29,6 \%)$, что мы объясняем общим социально - экономическим неблагополучием в Республике Тыва, по сравнению с другими национальными субъектами [7].

Подростки, имеющие по два или три негативных фактора социального влияния, отно- 
сятся к группе риска по формированию деструктивного, в том числе, суицидального поведения, и представляют собой контингент для целевого вмешательства социальных педагогов и психологов.

Выводы:

1. Социальные факторы риска, ассоциированные с суицидальным поведением, у подростков коренных популяций Сибири являются идентичными, но по частоте и выраженности имеют территориальные различия, с бо̀льшей распространённостью их в северных районах. Неблагополучное семейное окружение, проблемы взаимоотношений и проявления девиантного поведения у якутов, эвенов и эвенков встречаются в 1,5-2,5 раза чаще, по сравнению с алтайцами и бурятами $(\mathrm{p}<0,05)$. В семьях подростков тувинской национальности материально-бытовые проблемы и алкоголизация родителей встречаются также часто, как и у подростков, проживающих на севере.

2. При проведении корреляционного анализа выявлено, что склонность к употреблению алкоголя у подростков разных этнических групп связана с разными семейными рисками: у якутов - с наличием конфликтных отношений в семье $(\mathrm{p}<0,01)$, у алтайцев и тувинцев - c алкоголизацией родителей $(\mathrm{p}<0,01)$.

3. У 20,4\% якутов, у 19,1\% эвенов и эвенков, у 13,5\% алтайцев, у 7\% агинских бурят и 29,6\% тувинцев выявлены сочетания двух или трёх неблагоприятных социальных факторов. Эти подростки относятся к группе риска по формированию деструктивного, в том числе, суицидального поведения, и представляют собой контингент для целевого вмешательства социальных педагогов и психологов.

\section{Благодарности}

Автор выражает огромную благодарность за помощь в организации экспедиционных исследований директору РЦ ПМСС Республики Саха (Якутия) (РС (Я)), заслуженному работнику образования РС (Я) В.Н. Филиппову и его заместителю по учебно-методической работе, почётному работнику образования РФ, отличнику образования РС (Я) Т.Ф. Мартыновой; работникам администрации Агинского Бурятского округа Забайкальского края в лице консультанта отдела социального развития С.Б. Базарова и заместителя начальника отдела социального развития Р.М. Балдоржиевой; начальнику отдела образовательной политики Министерства образования и науки Республики Алтай О.С. Саврасовой.

Автор благодарит за помощь в проведении исследований работников образования и здравоохранения РС (Я): зав. отделом инновационных технологий РЦ ПМСС Министерства образования РС(Я) Р.Н. Андрееву; зав. РПМПК РЦ ПМСС Министерства образования РС (Я) И.И. Андрееву; педагогов-психологов РЦ ПМСС Министерства образования РС (Я) Е.Н. Семенову, А.Ф. Петрову и А.Н. Андросову; специалиста управления образованием Олекминского района Н.С. Макарову; врача психиатра ГУ ЯРПНД Минздрава РС (Я) Е.В. Мордосову; врача педиатра ЦБ Усть-Майского улуса Ю.Е. Ноеву; врачей психиатров РПМПК РЦ ПМСС Министерства образования РС (Я) Т.Н. Саввину и Т.С. Сивцеву.

Автор благодарен за помощь в сборе и обработке полученного материала научным сотрудникам ФИЦ КНЦ СО РАН, г. Красноярска: в.н.с., к.м.н. В.А. Вшивкову, в.н.с., к.м.н. А.Ю. Холомеевой; в.н.с., к.м.н. Л.В. Лаптевой; н.с. Н.Г. Муравьевой; медицинским психологам КГБУЗ ККПНД №1 А.Ф. Музафаровой, Е.Е. Долгушиной, Ю.Н. Орловой.

Литература:

1. Смертность российских подростков от самоубийств. М.: БЭСТ-принт, 2011. 131 с.

2. Федеральная служба государственной статистики: http://www.gks.ru

3. Семенова Н.Б. Причины суицидального поведения у коренных народов Сибири: религиозно-мировоззренческие аспекты отношения к смерти. Суицидология. 2018; 9 (1): 36-43.

4. Предотвращение самоубийств: глобальный императив. Женева: Всемирная организация здравоохранения, 2014. 102 с.

5. Семенова Н.Б. Причины суицидального поведения у коренных народов Сибири: смена традиционного образа жизни. Суииидология. 2017; 8 (4): 31-42.

6. Семенова Н.Б. Причины суицидального поведения у коренных народов Сибири: утрата ценностей патриархальной семьи. Суицидология. 2018; 9 (2): 3-15.

7. Семенова Н.Б. Причины суицидального поведения у коренных народов Сибири: социально-экономические факторы
References:

1. Smertnost' rossijskih podrostkov ot samoubijstv [The mortality of Russian teenagers from suicide]. M.: BJeST-print, 2011. 131 s. (In Russ)

2. Federal'naja sluzhba gosudarstvennoj statistiki [Federal state statistics service]: http://www.gks.ru (In Russ)

3. Semenova N.B. Causes of suicidal behavior in native peoples of Siberia: religious and world outlook aspects of attitude to death Suicidology. 2018; 9 (1): 36-43. (In Russ)

4. Predotvrashhenie samoubijstv: global'nyj imperativ. Zheneva [Suicide prevention: a global imperative]: Vsemirnaja organizacija zdravoohranenija, 2014. 102 s. (In Russ)

5. Semenova N.B. The causes of suicidal behavior in native peoples of Siberia: transition from traditional lifestyle. Suicidology. 2017; 8 (4): 31-42. (In Russ)

6. Semenova N.B. Reasons of suicidal behavior in native peoples of Siberia (Russia): the loss of the values of patriarchal family. Suicidology. 2018; 9 (2): 3-15. (In Russ)

7. Semenova N.B. Causes of suicidal behavior in indigenous peoples of Siberia: socio-economic risk factors. Suicidology. 
риска. Суицидология. 2018; 9 (3): 30-41.

8. Portzky G., Audenaert K., van Heeringen K. Suicide among adolescents. A psychological autopsy study of psychiatric, psychosocial and personality-related risk factors. Soc. Psychiatry Psychiatr. Epidemiol. 2005; 40 (11): 922-30.

9. Bilsen J. Suicide and Youth: Risk Factors. Front. Psychiatry. 2018; 9: 540. doi: 10.3389/fpsyt.2018.00540.

10. Sitnik-Warchulska K., Izydorczyk B. Family patterns and suicid$\mathrm{al}$ and violent behavior among adolescent girls-genogram analysis. Int. J. Environ. Res. Public Health. 2018; 20 (15-10). doi: 10.3390/ijerph15102067.

11. Gould M., Fisher P., Parides M., et al. Psychosocial risk factors of child and adolescent completed suicide. Arch. Gen. Psychiatry. 1996; 53 (12): 1155-62.

12. Johnson J.G., Cohen P., Gould M.S., et al. Childhood adversities, interpersonal difficulties, and risk for suicide attempts during late adolescence and early adulthood. Arch. Gen. Psychiatry. 2002; 59 (8): 741-9.

13. Chachamovich E., Kirmayer L.J., Haggarty J.M., et al. Suicide among Inuit: results from a large, epidemiologically representative follow-back study in Nunavut. Can. J. Psychiatry. 2015; 60 (6): 268-75.

14. Brockie T.N., Dana-Sacco G., Wallen G.R., et al. The Relationship of Adverse Childhood Experiences to PTSD, Depression, Poly-Drug Use and Suicide Attempt in Reservation-Based Native American Adolescents and Young Adults. Am. J. Community Psychol. 2015; 55 (3-4): 411-21.

15. Ворсина О.П. Клинико-социальные и этнокультуральные особенности суицидального поведения населения Иркутской области: дисс. ... док. мед. наук. Томск, 2012. 359 с.

16. Ворсина О.П., Дианова С.В., Белькова Т.Ю. Особенности суицидального поведения детей и подростков в Иркутске. Сибирский вестник психиатрии и наркологии. 2011; 68 (5): $20-4$.

17. Ворсина О.П. Социально-демографические и клинические характеристики детей и подростков, совершивших завершенные суициды. Сибирский вестник психиатрии и наркологии. 2016; 92 (3): 51-4.

18. Ишимбаева А.Н. Суицидальное поведение у детей и подростков Забайкальского края: автореф. дисс. ... канд. мед. наук. Москва, 2013. 23 с.

19. Злова Т.П., Ишимбаева А.Н., Ахметова В.В. Социальнопсихологические особенности незавершенных суицидов у детей и подростков. Суицидология. 2011; 2 (2): 27-8.

20. Семенова Н.Б., Мартынова Т.Ф. Анализ завершенных суицидов среди детей и подростков Республики Саха (Якутия). $\mathrm{Cu}$ бирский вестник психиатрии и наркологии. 2012; 72 (3): 42

21. Семенова Н.Б., Манчук В.Т. Медико-социальный статус подростков Республики Тыва. Проблемы соииальной гигиеHbl, здравоохранения и истории медициныл. 2007; 3: 17-20.

22. Семенова Н.Б. Социальный статус подростков Якутии. Проблемь сочиальной гигиень, здравоохранения и истории медииины. 2015; 4: 14-9.

23. Государственный доклад о положении детей и семей, имеющих детей, в Республике Саха (Якутия): 2014. http://old.sakha.gov.ru/node/280674

24. Государственный доклад о положении семей с детьми в Республике Тыва за 2016 год. http:/gov.tuva.ru/content/1418/
2018; 9 (3): 30-41. (In Russ)

8. Portzky G., Audenaert K., van Heeringen K. Suicide among adolescents. A psychological autopsy study of psychiatric, psychosocial and personality-related risk factors. Soc. Psychiatry Psychiatr. Epidemiol. 2005; 40 (11): 922-30.

9. Bilsen J. Suicide and Youth: Risk Factors. Front. Psychiatry. 2018; 9: 540. doi: 10.3389/fpsyt.2018.00540.

10. Sitnik-Warchulska K., Izydorczyk B. Family patterns and suicidal and violent behavior among adolescent girls-genogram analysis. Int. J. Environ. Res. Public Health. 2018; 20 (15-10). doi: 10.3390/ijerph15102067.

11. Gould M., Fisher P., Parides M., et al. Psychosocial risk factors of child and adolescent completed suicide. Arch. Gen. Psychiatry. 1996; 53 (12): 1155-62.

12. Johnson J.G., Cohen P., Gould M.S., et al. Childhood adversities, interpersonal difficulties, and risk for suicide attempts during late adolescence and early adulthood. Arch. Gen. Psychiatry. 2002; 59 (8): 741-9.

13. Chachamovich E., Kirmayer L.J., Haggarty J.M., et al. Suicide among Inuit: results from a large, epidemiologically representative follow-back study in Nunavut. Can. J. Psychiatry. 2015; 60 (6): 268-75.

14. Brockie T.N., Dana-Sacco G., Wallen G.R., et al. The Relationship of Adverse Childhood Experiences to PTSD, Depression, Poly-Drug Use and Suicide Attempt in Reservation-Based Native American Adolescents and Young Adults. Am. J. Community Psychol. 2015; 55 (3-4): 411-21.

15. Vorsina O.P. Kliniko-social'nye i jetnokul'tural'nye osobennosti suicidal'nogo povedenija naselenija Irkutskoj oblasti [Clinical, social and ethno-cultural features of suicidal behavior of the population of the Irkutsk region]: diss. ... dok. med. nauk. Tomsk, 2012. 359 s. (In Russ)

16. Vorsina O.P., Dianova S.V., Bel'kova T.Ju. Osobennosti suicidal'nogo povedenija detej i podrostkov v Irkutske [Features of suicidal behavior of children and adolescents in Irkutsk]. Sibirskij vestnik psihiatrii $i$ narkologii [Siberian journal of psychiatry and narcology]. 2011; 68 (5): 20-4. (In Russ)

17. Vorsina O.P. Social'no-demograficheskie i klinicheskie harakteristiki detej i podrostkov, sovershivshih zavershennye suicidy [Socio-demographic and clinical characteristics of children and adolescents who have committed completed suicide]. Sibirskij vestnik psihiatrii $i$ narkologii [Siberian journal of psychiatry and narcology]. 2016; 92 (3): 51-4. (In Russ)

18. Ishimbaeva A.N. Suicidal'noe povedenie u detej i podrostkov Zabajkal'skogo kraja [Suicidal behavior in children and adolescents of the Trans-Baikal territory]: avtoref. diss. ... kand. med. nauk. Moskva, 2013. 23 s. (In Russ)

19. Zlova T.P., Ishimbaeva A.N., Ahmetova V.V. Sociallypsychological features of incomplete suicides at children and teenagers (Transbaikalian edge, Chita). Suicidology. 2011; 2 (2): 27-8. (In Russ)

20. Semenova N.B., Martynova T.F. Analiz zavershennyh suicidov sredi detej i podrostkov Respubliki Saha (Jakutija) [Analysis of completed suicides among children and adolescents of the Republic of Sakha (Yakutia)]. Sibirskij vestnik psihiatrii $i$ narkologii [Siberian journal of psychiatry and narcology]. 2012; 72 (3): 42-5. (In Russ)

21. Semenova N.B., Manchuk V.T. Mediko-social'nyj status podrostkov Respubliki Tyva [Medical and social status of adolescents of the Republic of Tuva]. Problemy social'noj gigieny, zdravoohranenija $i$ istorii mediciny [Problems of social hygiene, health care and medical history]. 2007; 3: 17-20. (In Russ)

22. Semenova N.B. Social'nyj status podrostkov Jakutii [Social status of adolescents in Yakutia]. Problemy social'noj gigieny, zdravoohranenija $i$ istorii mediciny [Problems of social hygiene, health care and medical history]. 2015; 4: 14-9. (In Russ)

23. Gosudarstvennyj doklad o polozhenii detej i semej, imejushhih detej, v Respublike Saha (Jakutija): 2014 [State report on the situation of children and families with children in the Republic of Sakha (Yakutia): 2014]. http://old.sakha.gov.ru/node/280674 (In Russ)

24. Gosudarstvennyj doklad o polozhenii semej s det'mi v Respublike Tyva za 2016 god [State report on the situation of families 
25. https://www.bankfax.ru/news/104658

26. http://www.aginskpravda.ru/news/siloviki_okruga_podveli_itogi_raboty/2016-0126-4265

27. Cwik M., Barlow A., Tingey L, et al. Exploring risk and protective factors with a community sample of American Indian adolescents who attempted suicide. Arch. Suicide Res. 2015; 19 (2): 172-89.

28. Ballard E.D., Musci R.J., Tingey L., et al. Latent class analysis of substance use and aggressive behavior in reservation-based American Indian youth who attempted suicide. Am. Indian Alsk. Native Ment. Health. 2015; 22 (1): 77-94.

29. Harford T.C., Chen C.M., Grant B.F. Other - and self-directed forms of violence and their relationship with number of substance use disorder criteria among youth ages 12-17: results from the national survey on drug use and health. J. Stud. Alcohol Drugs. 2016; 77 (2): 277-86. with children in the Republic of Tuva for 2016]. http://gov.tuva.ru/content/1418/ (In Russ)

25. https://www.bankfax.ru/news/104658

26. http://www.aginsk-

pravda.ru/news/siloviki_okruga_podveli_itogi_raboty/201601-26-4265

27. Cwik M., Barlow A., Tingey L, et al. Exploring risk and protective factors with a community sample of American Indian adolescents who attempted suicide. Arch. Suicide Res. 2015; 19 (2): 172-89.

28. Ballard E.D., Musci R.J., Tingey L., et al. Latent class analysis of substance use and aggressive behavior in reservation-based American Indian youth who attempted suicide. Am. Indian Alsk. Native Ment. Health. 2015; 22 (1): 77-94.

29. Harford T.C., Chen C.M., Grant B.F. Other - and self-directed forms of violence and their relationship with number of substance use disorder criteria among youth ages 12-17: results from the national survey on drug use and health. J. Stud. Alcohol Drugs. 2016; 77 (2): 277-86.

\title{
SUICIDE BEHAVIOR IN SIBERIA NATIVE CHILDREN AND ADOLESCENTS: SOCIAL RISK FACTORS
}

\author{
N.B. Semenova
}

Federal Research Centre "Krasnoyarsk Scientific Centre of Siberian Division of Russian Academy of Sciences", Scientific Research Institute for Medical Problems of the North, Krasnoyarsk, Russia; snb237@gmail.com

\section{Abstract:}

Suicide mortal cases related to Siberia native children and adolescents are many times more frequent as compared to average indices in Russian Federation. This requires thorough analysis for this social phenomenon and its reasons. Aim of the Research. To estimate the prevalence and pronouncement of social risk factors, which are associated with suicide behavior in adolescents of Siberia native populations - the Yakuts, the Evens, the Evenks, the Altayans, the Aginsk Buryats and the Tyvins. Subjects and Methods of the Study. We examined 781 adolescents of different ethnic groups by anonymous questionnaire: the Yakuts (181), the Evens and Evenks (63), the Altayans (103), the Buryats (228), the Tyvins (206). The Yakuts, the Evens and the Evenks inhabit northern regions and the Altayans, the Buryats and the Tyvins inhabit southern regions of Siberia. Average age of the adolescents was 16.5 years. We have studied three groups of risk factors: I. Family risk factors (family problems in regard to housing conditions; intrafamily problems; conflicts in the family; drinking parents); II. Risks related to the system of relationships (problems in the relationships with parents, teachers, peers, the opposite sex); III. Deviant activity risks (alcohol and/or psychoactive preparations (PAP) consumption; alcoholic and/or PAP friends; criminal friends). Statistical processing of the data had been worked out with Statistica for Window Version X program. Results. Family risks were found in 7.8$29.8 \%$ adolescents; risks related to relationships in 9.6-43.1\%; deviant activity risks in 7.8-69.8\%. Combination of negative influence of two or three factors had been revealed in 7.0-29.6\% adolescents. The prevalence of social risk factors is more frequent in adolescents, inhabiting northern regions of Siberia - the Yakuts, the Evens, the Evenks $(p<0.01)$. In Tyvin adolescents housing problems and parental alcoholism are as frequent as in the adolescents, living in the North. Conclusions. In 20.4\% Yakuts, in 19.1\% Evens and Evenks, in $13.5 \%$ Altayans, in $7 \%$ Aginsk Buryats and in $29.6 \%$ Tyvins we have found the combinations of two or three unfavorable social factors. Those adolescents require special preventive measures.

Keywords: adolescents, suicide, native peoples of Siberia, indigenous, aborigines, risk factors, North

Финансирование: Исследование выполнено при финансовой поддержке грантов РГНФ № 12-06-18006 «Социальные и этнопсихологические предпосылки суицидального поведения у подростков Бурятии"; гранта РГНФ № 13-06-18001 "Социальные и этнопсихологические предпосылки формирования суицидального поведения у подростков Республики Алтай»; контракта НИР №12-01/06 от 12.07.2013 г. «Закономерности формирования психического здоровья коренных и малочисленных народов Республики Саха (Якутия)».

Конфмикт интересов: Автор заявляет об отсутствии конфликта интересов.

Для цитирования: Семёнова Н.Б. Суицидальное поведение у детей и подростков коренных народов Сибири: социальные факторы риска. Суицидология. 2018; 9 (4): 3-16. doi.org/10.32878/suiciderus.18-09-04(33)-3-16

For citation:

Semenova N.B. Suicide behavior in Siberia native children and adolescents: social risk factors. Suicidology. 2018; 9 (4): 3-16. (In Russ) doi.org/10.32878/suiciderus.18-09-04(33)-3-16 